\title{
The Kimberlite-Megacryst link at Monastery Mine
}

Hatton, C.J.

Anglo American Research Laboratories (Pty) Ltd., P.O. Box 106, Crown Mines 2025, Johannesburg.

The megacryst suite at Monastery Mine is divided into two suites; the Main Silicate Suite and the Phlogopite Suite. Evolution of both suites was by simple fractional crystallisation from two distinct primary magmas.

The Main Silicate Suite consists of the following assemblages;

- Orthopyroxene $(\mathrm{mg} \#<92)$

- Olivine-orthopyroxene-clinopyroxene-garnet

- Olivine $_{0.57}$-orthopyroxene $e_{0.19}$-clinopyroxene ${ }_{0.071}$-garnet - $_{0.12}$-ilmenite $_{0.05}$

- Calcite $_{0.6}$-serpentine 0.35 -ilmenite - $_{0.05}$

- Calcite $_{0.95}$-ilmenite 0.05 -zircon 0.0001 .

The presence of calcite and serpentine as inclusions in ilmenite is documented by Kirkley (1987) and their high modal abundance is inferred by $\mathrm{Nb}-\mathrm{Zr}$ fractionation trends which show that ilmenite must be a minor component of fractionating assemblages (Moore et al., 1992). The absence of serpentine from the calciteilmenite-zircon paragenesis is shown by the increase in $\mathrm{MgO}$ content of ilmenite during fractionation of this assemblage. The absence of silicates from the calcitebearing parageneses is inferred by increasing $\mathrm{Cr}$ in ilmenite during their fractionation.

The Phlogopite suite consists of

- Orthopyroxene (mg\#>92)

- Phlogopite-ilmenite

- Phlogopite-olivine $(\mathrm{mg} \#<83)$-ilmenite-zircon.

Assemblages coexisting with zircon were included in a single group (Group 2) by Moore et al. (1992) and the higher Mg content of ilmenite in the phlogopite-olivineilmenite-zircon paragenesis was attributed to the influx of new magma; here this paragenesis is simply regarded as the fractionated successor to the phlogopite-ilmenite paragenesis (Group 3 of Moore et al., 1992).

High mg\# orthopyroxene is included in the Phlogopite Suite because phlogopite has mg\# 1 unit lower than coexisting orthopyroxene (Nixon and Boyd, 1973) so phlogopite, with mg\# up to 91 , could succeed orthopyroxene with mg\# 92.

Crystallisation of monomineralic orthopyroxene, without olivine, is difficult to explain if the melting assemblage is garnet lherzolite. The hypothesis offered here is that the melting assemblage contained sufficient kyanite- or coesite-bearing eclogite to drive the initial cumulate assemblage, normally expected to contain olivine, onto the eclogite thermal divide which separates silica-oversaturated assemblages from olivine-bearing assemblages. Crystallisation of monominerallic orthopyroxene is permissible in the plane of the eclogite thermal divide (O'Hara and Yoder, 1967). 
Involvement of an eclogitic/pyroxenitic assemblage in the Monastery megacryst suites is supported by radiogenic Os in ilmenite (Carlson and Bell, 1997). More generally a mixed peridotite-eclogite mantle has been proposed in the source of oceanic magmas (Schiano et al., 1997 and refs. therein). Mantle inhomogeneity, on a scale of $8 \mathrm{~km}$, is supported by seismic data (Hedlin et al., 1997). The major isotopic components of the mantle. DMM, EM2, EM1 and HIMU (Zindler and Hart, 1986) could therefore be present in heterogeneous mantle plumes. The EM1 signature is not prominent is South African Cretaceous kimberlites, so the genesis of the Monastery megacrysts is considered in terms of a rising plume containing DMM, EM2 and HIMU components. The HIMU component is considered to be volatile-rich because its presence enhances melting; Hanan and Schilling (1997) record that the higher the proportion of HIMU-like component, the higher the extrusion rate of lava, and Chauvel et al. (1992) calculated that the depth and temperature of melting was highest in HIMU rocks.

The first melt extract from the Monastery plume provided the source magma for the Main Silicate Suite. Reaction between peridotitic DMM and eclogitic EM2 resulted in orthopyroxene crystallisation, prior to crystallisation of the usual mantle assemblage of olivine-orthopyroxene-clinopyroxene-garnet. Enhancement of $\mathrm{Ti}$ levels by the EM2 component brought ilmenite onto the liquidus. The volatile contribution from HIMU then led to calcite and serpentine crystallisation from highly fractionated magma.

The rise of the plume was stalled by the subcontinental lithosphere. Fluxing of the hot plume by volatiles in the lithosphere, dominantly provided by phlogopite. generated a high mg\# second-stage melt, parental to the Phlogopite Suite. The lithosphere contribution is manifested by high ${ }^{87} \mathrm{Sr} /{ }^{86} \mathrm{Sr}$ ratios in phlogopite megacrysts (Allsopp and Barrett, 1975).

Finally, melt derived from the volatile-rich HIMU component of the cooling plume ponded to form the Monastery kimberlite, which transported the crystallised products of the two earlier melts to the surface.

\section{References.}

Allsopp HL. Barrett DR (1975) Rb-Sr age determinations on South African kimberlite pipes. Physics and Chemistry of the Earth 9:605-617

Carlson RW, Bell DR (1997) Re-Os systematics of kimberlite megacryst inclusions: implications for the source of kimberlitic magmas. VM Goldschmidt Conference, Abstracts.

Chauvel C., Hofmann AW, Vidal P (1992) HIMU-EM: The French Poynesian connection. Earth and Planetary Science Letters 110:99-119.

Hanan BB, Schilling J-G (1997) The dynamic evolution of the Iceland mantle plume: the lead isotope perspective. Earth and Planetary Science Letters 151:43-60.

Hedlin MAH. Shearer PM, Earle PS (1997) Seismic evidence of small-scale heterogeneity throughout the Earth's mantle. Nature 387:145-150. 
Kirkley MB (1987) Aspects of the geochemistry of kimberlite carbonates. Unpublished Ph D thesis, University of Cape Town, 281 pp.

Moore RO, Griffin WL. Gurney JJ, Ryan CG, Cousens DR, Sie SH, Suter GF (1992) Trace element geochemistry of ilmenite megacrysts from the Monastery Kimberlite, South Africa. Lithos 29:1-18.

Nixon PH, Boyd FR (1973) Petrogenesis of the granular and sheared ultrabasic nodule suite in kimberlites. In Nixon PH (editor) Lesotho Kimberlites. Lesotho National Development Corporation, Maseru. pp. 48-56.

O'Hara MJ, Yoder HS Jr (1967) Formation and fractionation of basic magmas at high pressures. Scottish Journal of Geology 3:67-117.

Schiano P, Birck J-L, Allègre CJ (1997) Osmium-strontium-neodymium-lead isotopic covariations in mid-ocean ridge basalt glasses and the heterogeneity of the upper mantle. Earth and Planetary Science Letters 150:363-379.

Zindler A, Hart S (1986) Chemical geodynamics. Annual Review of Earth and Planetary Science Letters 14:493-571. 